\title{
STRAW DECOMPOSITION OF NITROGEN-FERTILIZED GRASSES INTERCROPPED WITH IRRIGATED MAIZE IN AN INTEGRATED CROP-LIVESTOCK SYSTEM ${ }^{(1)}$
}

\author{
Cristiano Magalhães Pariz ${ }^{(2)}$, Marcelo Andreotti( ${ }^{(3)}$, Salatiér \\ Buzetti $^{(3)}$, Antonio Fernando Bergamaschine ${ }^{(4)}$, Nelson de Araújo \\ Ulian $^{(5)}$, Luciano Coletti Furlan ${ }^{(6)}$, Paulo Roberto de Lima \\ Meirelles $^{(7)}$ \& Francielli Aparecida Cavasano ${ }^{(5)}$
}

\begin{abstract}
SUMMARY
The greatest limitation to the sustainability of no-till systems in Cerrado environments is the low quantity and rapid decomposition of straw left on the soil surface between fall and spring, due to water deficit and high temperatures. In the 2008/2009 growing season, in an area under center pivot irrigation in Selvíria, State of Mato Grosso do Sul, Brazil, this study evaluated the lignin/total N ratio of grass dry matter, and N, P and $\mathrm{K}$ deposition on the soil surface and decomposition of straw of Panicum maximum cv. Tanzânia, P. maximum cv. Mombaça, Brachiaria. brizantha cv. Marandu and B. ruziziensis, and the influence of $\mathrm{N}$ fertilization in winter/spring grown intercropped with maize, on a dystroferric Red Latosol (Oxisol). The experiment was arranged in a randomized block design in splitplots; the plots were represented by eight maize intercropping systems with grasses (sown together with maize or at the time of $\mathrm{N}$ side dressing). Subplots consisted of $\mathrm{N}$ rates $\left(0,200,400\right.$ and $800 \mathrm{~kg} \mathrm{ha}^{-1}$ year $\left.^{-1}\right)$ sidedressed as urea (rates split in four applications at harvests in winter/spring), as well as evaluation of the straw
\end{abstract}

\footnotetext{
(1) Part of the master work of first author developed at the College of Engineering, State University of the São Paulo - UNESP. Financial supporting and scholarship to first author Capes. Received for publication in February 2, 2011 and approved September 1, 2011.

${ }^{(2)}$ Doctoral Student at the Post-Graduation Program in Animal Science at the FMVZ in the UNESP. Distrito de Rubião Júnior s/n, Fazenda Lageado, C.P. 560, CEP 18618-970 Botucatu (SP). Bolsista da FAPESP. E-mail: cmpzoo@gmail.com

(3) Teacher at the Department of Rural Engineering and Soils at the FE in the UNESP. Rua Monção 226, Zona Norte, C.P. 31, CEP 15385-000 Ilha Solteira (SP). Bolsista do CNPQ. E-mails: dreotti@agr.feis.unesp.br; sbuzetti@agr.feis.unesp.br

(4) Teacher at the Department of Biology and Animal Science at the FE in the UNESP. Rua Monção 226, Zona Norte, C.P. 31, CEP 15385-000 Ilha Solteira (SP). E-mail: berga@bio.feis.unesp.br

(5) Master Student at the Post-Graduation Program in Animal Science at the FMVZ at the UNESP. Distrito de Rubião Júnior, s/n, Fazenda Lageado, CP 560, CEP 18.618-970 Botucatu (SP). Bolsista da FAPESP. E-mails: nelsinhoulian@yahoo.com; fran_cavasano@yahoo.com.br

(6) Agronomy Student at the FE in the UNESP. E-mail: luciano_coletti@hotmail.com

(7) Teacher at the Department of Animal Nutrition and Breeding at the FMVZ at the UNESP. E-mail: paulom@fmvz.unesp.br
} 
decomposition time by the litter bag method $(15,30,60,90,120$, and 180 days after straw chopping). Nitrogen fertilization in winter/spring of $P$. maximum cv. Tanzânia, $P$. maximum cv. Mombaça, B. brizantha cv. Marandu and $B$. ruziziensis after intercropping with irrigated maize in an integrated crop-livestock system under no-tillage proved to be a technically feasible alternative to increase the input of straw and $N, P$ and $K$ left on the soil surface, required for the sustainability of the system, since the low lignin/ $\mathrm{N}$ ratio of straw combined with high temperatures accelerated straw decomposition, reaching approximately $30 \%$ of the initial amount, 90 days after straw chopping.

Index terms: Brachiaria, Panicum maximum, lignin/N ratio, no-tillage system, Zea mays $\mathrm{L}$.

\title{
RESUMO: DECOMPOSIÇÃO DA PALHADA DE CAPINS ADUBADOS COM NITROGÊNIOAPÓSO CONSÓRCIO COMACULTURADO MILHO EMSISTEMADE INTEGRAÇÃO LAVOURA-PECUÁRIA IRRIGADO
}

\begin{abstract}
A maior limitação para a sustentabilidade do sistema plantio direto no Cerrado é a pequena deposição e a rápida decomposição da palhada na superfície do solo entre o outono e a primavera, em razão dos déficits hídricos e das temperaturas elevadas. No ano agrícola de 2008/2009, em área irrigada por pivô central no município de Selvíria, Estado de Mato Grosso do Sul, objetivou-se avaliar a relação lignina/ $N$ total, a deposição de N, Pe K sobre a superfície do solo e a decomposição da palhada dos capins Panicum maximum cv. Tanzânia, P. maximum $c v$. Mombaça, Brachiaria. brizantha $c v$. Marandu e B. ruziziensis em função da adubação nitrogenada no inverno/primavera, após o consórcio com a cultura do milho, num Latossolo Vermelho distroférrico em condições de Cerrado. O delineamento experimental foi o de blocos casualizados em esquema de parcelas subdivididas, constituído nas parcelas por oito consórcios da cultura do milho com os capins (semeado simultaneamente ou por ocasião da adubação nitrogenada de cobertura) e, nas subparcelas, pela ausência de adubação e por doses de 200, 400 e $800 \mathrm{~kg} \mathrm{ha}^{-1} \mathrm{ano}^{-1}$ de $\mathrm{N}$ aplicadas em cobertura na pastagem após o consórcio com a cultura do milho, na forma de ureia (parceladas em quatro épocas de corte no inverno/primavera), bem como pelo tempo de decomposição da palhada avaliada pelo método do "Litter Bag" (15, 30, 60, 90, 120 e 180 dias após o manejo mecânico com triturador horizontal de resíduos vegetais - triton). A adubação nitrogenada dos capins $\mathrm{P}$. maximum $c v$. Tanzânia, P. maximum $c v$. Mombaça, B. brizantha $c v$. Marandu e B. ruziziensis após o consórcio com a cultura do milho na integração lavoura-pecuária sob sistema plantio direto irrigado mostrou-se uma alternativa tecnicamente viável na elevação do aporte de palhada e da quantidade de N, Pe K depositada sobre a superfície do solo, necessária para a continuidade desse sistema, visto que a baixa relação lignina/ $N$ total da palhada, aliada às altas temperaturas, acelerou a sua decomposição, atingindo aproximadamente $30 \%$ da quantidade inicial aos 90 dias após o manejo com triton.
\end{abstract}

Termos de indexação: Brachiaria, Panicum maximum, relação lignina/N total, sistema plantio direto, Zea mays $L$.

\section{INTRODUCTION}

The greatest limitation of the sustainability of notill systems in the Cerrado is the low quantity and rapid decomposition of straw left on the soil surface between fall and spring, due to water deficit and high temperatures. Factors such as these increase the likelihood of failure of fall crops ("safrinha" - second growing season), resulting in fallow agricultural areas during seven months of the year, compromising the success of no-till systems (Kluthcouski et al., 2003). In this context, integrated crop-livestock systems represent a viable alternative of year-round use of agricultural areas (Pariz et al., 2011).

According to Pariz et al. (2009b), despite the advantages of integrated crop-livestock systems over non-integrated crop systems, their success depends on a comprehensive knowledge of the system as a whole. In this context, according to Balbinot Júnior et al. (2009), integrated crop-livestock systems require the practice of five basic fundamentals: 1) correction of soil acidity and fertility; 2) use of no-till systems; 3) crop rotation; 4) use of improved animal and vegetal genotypes with high yield potential and the desired 
qualitative and robustness parameters; and 5) adequate pasture management, particularly in terms of fertilization and pasture height.

The formation of a good straw cover on the soil surface is the primary condition for maximum efficiency of a no-till system (Kluthcouski \& Stone, 2003). Integrated crop-livestock systems represent an alternative, through the intercropping of grain crops and tropical forage plants, mainly of the genera Panicum and Brachiaria, in fields with partially or fully eliminated soil acidity. Therefore, this system of tropical grasses produces forage in the dry season and makes straw available for no-till systems, eliminating the need of cover-crop sowing in winter/ spring (Kluthcouski et al., 2000).

Perennial forage species in integrated croplivestock systems, aside from satisfactory amounts of forage in regions with dry winters, produce straw with greater persistence on soil after desiccation. Crusciol (2007) demonstrated in Botucatu, São Paulo State, Brazil, that 51 days after desiccation, less than $50 \%$ of straw millet was left, whereas nearly $70 \%$ of Marandu and Mombaça grass straw still remained on the ground.

Kliemann et al. (2006) studied the decomposition rates of cover crop residues on a Red Latosol (Oxisol) and concluded that the most fragile and least persistent straws were, in decreasing order: mombaça grass, grain sorghum, millet, stylosanthes, pigeon pea, marandu grass grown alone and with maize, respectively. The relative losses of straw dry matter after 150 days showed the following decreasing order of decomposition: grain sorghum (80 \%), stylosanthes (72\%), pigeon pea (65\%), mombaça grass $(64 \%)$, millet (58\%), marandu grass grown alone $(56 \%)$ and with maize (48\%).

If $\mathrm{N}$ is insufficiently supplied, the dry matter yield and consequently soil cover, particularly of grass species, are limited (Garay et al., 2004); the N concentrations in the cell wall components and the lignin/N ratio determine the perenniality of soil covers and subsequent nutrient mineralization, especially of $\mathrm{N}$. In the case of intercropping, competition for $\mathrm{N}$ may occur between maize and grass. The purpose of this study was to determine the lignin/ $\mathrm{N}$ ratio and decomposition of straw of Panicum maximum cv. Tanzânia, P. maximum cv. Mombaça, Brachiaria brizantha cv. Marandu and B. ruziziensis cv. Comum, due to $\mathrm{N}$ fertilization in winter/spring, grown intercropped with maize.

\section{MATERIAL AND METHODS}

The study was carried out in the 2008/09 growing season, on an experimental farm (Fazenda Experimental de Ensino e Pesquisa da Faculdade de Engenharia) of the State University of São Paulo (UNESP, Campus Ilha Solteira), in Selvíria, state of Mato Grosso do Sul (20202 50" S; 51242 26" W; 335 m asl), Brazil. The climate type is Aw (Köppen classification) (Figure 1).

According to the classification of Embrapa (2006), the soil in the area is a dystroferric Red Latosol (Oxisol). The physical and chemical properties prior to the experiment in the $0-0.20 \mathrm{~m}$ surface layer were determined as follows: soil density $=1.31 \mathrm{~kg} \mathrm{dm}^{-3}$; macro, micro and total porosity $=0.147 ; 0.334$ and $0.481 \mathrm{~m}^{3} \mathrm{~m}^{-3}$, respectively; $\mathrm{pH}\left(\mathrm{CaCl}_{2}\right)=5.1 ; \mathrm{OM}=$ $28 \mathrm{~g} \mathrm{dm}^{-3} ; \mathrm{H}+\mathrm{Al}=22.2 \mathrm{mmol}_{\mathrm{c}} \mathrm{dm}^{-3} ; \mathrm{P}($ resin $)=$ $18 \mathrm{mg} \mathrm{dm}^{-3} ; \mathrm{K}^{+}, \mathrm{Ca}^{2+}$ and $\mathrm{Mg}^{2+}=3.2,19.0$ and $11.0 \mathrm{mmol}_{\mathrm{c}} \mathrm{dm}^{-3}$, respectively; and base saturation $(\mathrm{V})$ $=59.9 \%$, according to the method described by Raij et al. (2001). In November 2008, in a pre-experimental stage, the area had been managed for six years under notill and the preceding crop had been maize intercropped with grass. The area was irrigated by a center-pivot sprinkler system, due to water deficit.

The experiment was evaluated in a randomized block design in split-plots with four replications. Plots consisted of eight treatments (pasture) with four grass species in maize-grass intercropping in the 2007/08 growing season: $P$. maximum cv. Tanzânia, $P$. maximum cv. Mombaça, B. brizantha cv. Marandu, B. ruziziensis grass sown together with maize (with maize), and sown at the time of maize $\mathrm{N}$ sidedressing (at $\mathrm{N}$ fertilization); in the subplots, the $\mathrm{N}$ rates applied to the grasses (0 (control), 200, 400 and $800 \mathrm{~kg} \mathrm{ha}^{-1}$ year $^{-1}$ of $\mathrm{N}$ ), split in four applications at harvests in winter/spring.

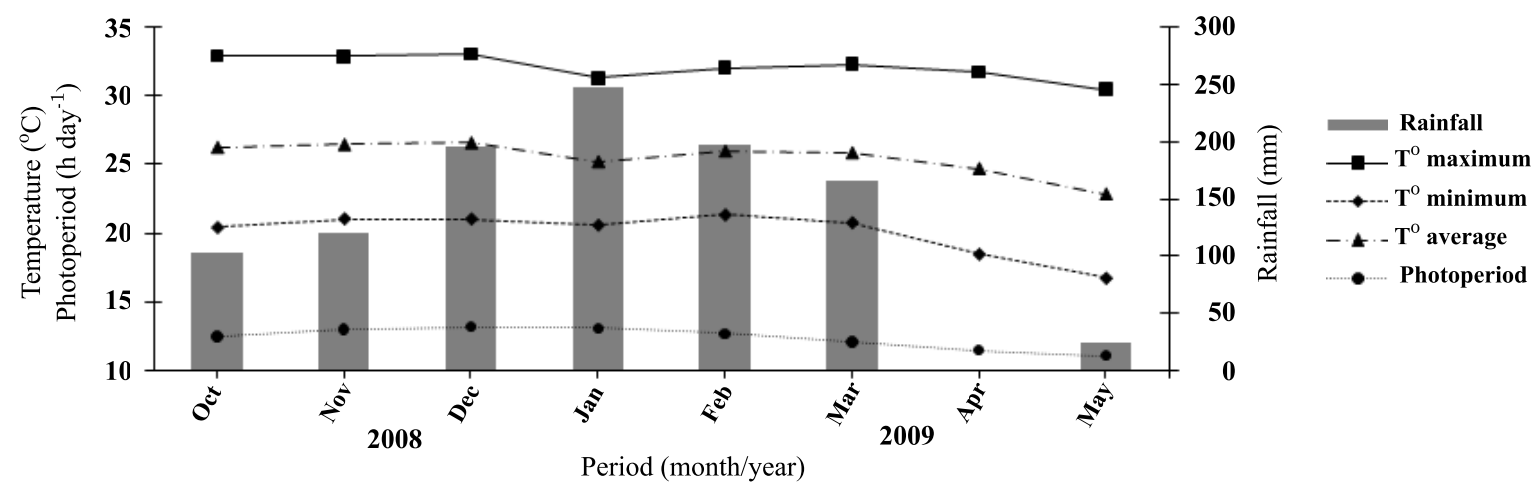

Figure 1. Climate data during the experimental period. Selvíria-MS. 2008 to 2009. 
The net plot area was 90 and $18 \mathrm{~m}^{2}$ in the subplots. The simple hybrid (SH) AG 8088 was sown (early cycle - high grain yield (0.90 m row spacing)). Mineral fertilization at sowing consisted of $20 \mathrm{~kg} \mathrm{ha}^{-1} \mathrm{~N}$, $70 \mathrm{~kg} \mathrm{ha}^{-1} \mathrm{P}_{2} \mathrm{O}_{5}$ and $40 \mathrm{~kg} \mathrm{ha}^{-1} \mathrm{~K}_{2} \mathrm{O}\left(250 \mathrm{~kg} \mathrm{ha}^{-1} \mathrm{NPK}\right.$ fertilizer 08-28-16) and side dressing consisted of $120 \mathrm{~kg} \mathrm{ha}^{-1} \mathrm{~N}$ (urea).

The grasses were sown $\left(7 \mathrm{~kg} \mathrm{ha}^{-1}\right.$ of seeds, pure live seed index $=76 \%$ ) at a distance of $0.34 \mathrm{~m}$ from maize rows. In the plots where grasses were sown together with maize (November 10, 2007), a special seeding-fertilizer machine for no-till systems was used for mechanized sowing, whereas in the plots where the grasses were sown at the time of $\mathrm{N}$ side dressing (December 19, 2007) the seeds were mixed with fertilizer minutes before sowing and placed in the fertilizer compartment of the seeding-fertilizer machine. In all intercrops, grass seeds were placed in the soil at a depth of $0.03 \mathrm{~m}$. Nicosulfuron herbicide $\left(8 \mathrm{~g} \mathrm{ha}^{-1}\right.$ active ingredient (ai)) was applied on December 17, 2007, to reduce the growth of grasses sown together with maize.

Maize was harvested on April 25, 2008 and the plots were leveled using a straw chopper on June 10, 2008. The grasses were cut on $7 / 30 / 2008,8 / 29 / 2008$, 9/29/2008, and 10/29/2008. Fertilization was carried out immediately after cutting the grass by mechanical mowers $(0.40 \mathrm{~m}$ and $0.30 \mathrm{~m}$ above soil level for Panicum and Brachiaria, respectively), and removing it from the site.

On November 7, 2008, the experimental area was desiccated using herbicides Glyphosate (1.44 kg ha-1 ai) and 2,4-D amine $\left(670 \mathrm{~g} \mathrm{ha}^{-1} \mathrm{ai}\right)$. On November 13,2008 , before the grasses were chopped with a machine of straw fragmentation and $0.25 \mathrm{~m}^{2}$ of grasses straw was collected from the sublot from the subplot (metal square), cut to $0.05 \mathrm{~m}$ above the soil surface, to determine residual dry matter (forage) (oven-dried at $65^{\circ} \mathrm{C}$ to constant mass), extrapolated to $\mathrm{kg} \mathrm{ha}^{-1}$. Laboratory tests were carried out to determine the levels of $\mathrm{N}, \mathrm{P}$ and $\mathrm{K}$, as described by Malavolta et al. (1997), and the levels of lignin, according to the methodology described by Silva \& Queiroz (2002) for calculating the lignin/ $\mathrm{N}$ ratio. Proportional quantities of residual fresh matter from each subplot were placed in six litter bags with $0.06 \mathrm{~m}^{2}$ $(0.3 \times 0.2 \mathrm{~m})$, left on the subplots and collected 15 , $30,60,90,120$, and 180 days after straw chopping to evaluate the straw remains (oven-dried at $65^{\circ} \mathrm{C}$ to constant mass), extrapolated to $\mathrm{kg} \mathrm{ha}^{-1}$. The levels of $\mathrm{N}, \mathrm{P}$ and $\mathrm{K}$ were multiplied by the straw amount and extrapolated to $\mathrm{kg} \mathrm{ha}^{-1}$, resulting in the amount of these nutrients left on the soil surface. Maize was sown over this fodder in $0.90 \mathrm{~m}$ row spacing.

Data were subjected to analysis of variance by $\mathrm{F}$ test $(\mathrm{p}<0.05)$ and adjusted using regression analysis (orthogonal polynomials), adopting the highest-level equation $(p<0.05)$. Statistical analyses were carried out using SISVAR ${ }^{\circledR}$ statistical software (Ferreira, 1999).

\section{RESULTS AND DISCUSSION}

The lignin/ $\mathrm{N}$ ratio of most intercrops - with the exception of tanzania grass with maize and mombaça grass at $\mathrm{N}$ fertilization - was influenced by the effect of $\mathrm{N}$ rates applied to pasture in winter/spring, with quadratic adjustments for the intercrops marandu grass with maize, ruziziensis grass with maize, marandu grass at $\mathrm{N}$ fertilization and ruziziensis grass at $\mathrm{N}$ fertilization, treated with rates resulting in minimum values of $557.00,507.58,590.83$ and $662.58 \mathrm{~kg} \mathrm{ha}^{-1}$ year ${ }^{-1}$ of $\mathrm{N}$, with lignin/ $\mathrm{N}$ ratios of 1.81 , $2.95,1.60$ and 2.57, respectively, while marandu grass with maize and tanzania grass at $\mathrm{N}$ fertilization showed a decreasing linear effect as a function of $\mathrm{N}$ rates (Figure 2). These results may have been influenced by the larger number of geniculate stems

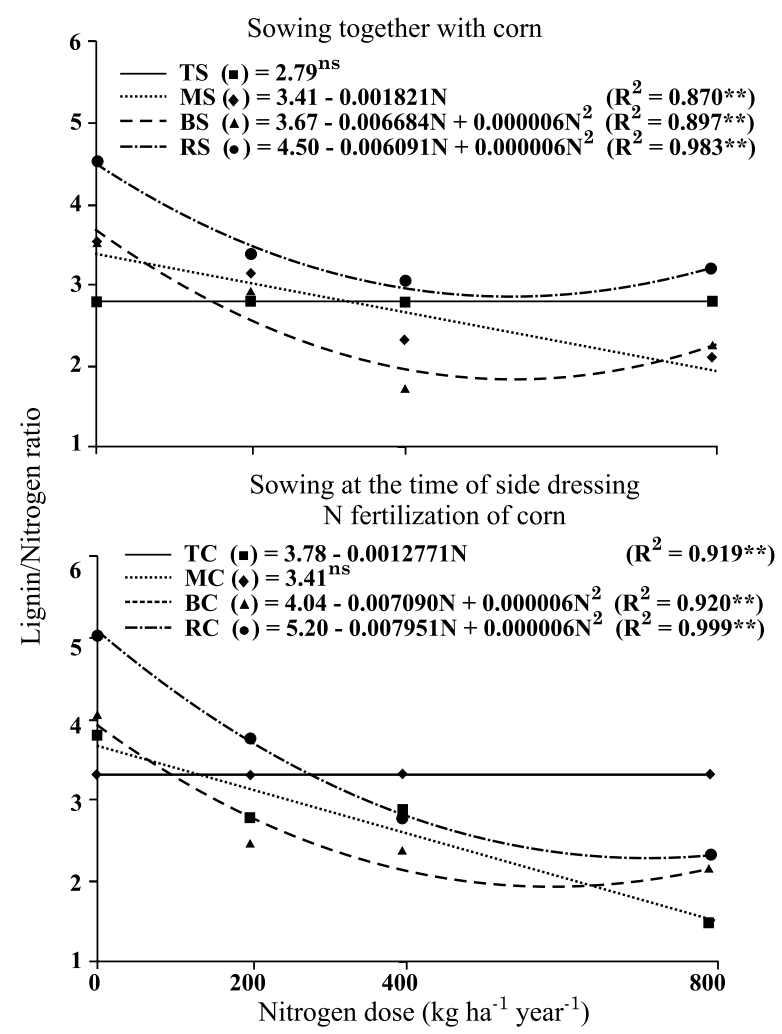

Figure 2. Lignin/Nitrogen ratio of straw of Panicum maximum cv. Tanzânia, P. maximum cv. Mombaça, Brachiaria brizantha cv. Marandu and $B$. ruziziensis grown intercropped with maize, Nfertilized (split in four applications at harvest) and chopped after the last cut of winter/spring. Selvíria-MS. 2008. TS, MS, BS and RS: Panicum maximum cv. Tanzânia, Panicum maximum cv. Mombaça, Brachiaria brizantha cv. Marandu and Brachiaria ruziziensis sown together with maize, respectively; TC, $\mathrm{MC}, \mathrm{BC}$ and $\mathrm{RC}$ : Panicum maximum cv. Tanzânia, $P$. maximum cv. Mombaça, Brachiaria brizantha cv. Marandu and $B$. ruziziensis sown at the time of $\mathrm{N}$ side dressing of maize, respectively. ${ }^{* *}, \mathrm{~ns}:(\mathrm{p}<0.01)$ and $(p>0.05)$, respectively. 
of B. ruziziensis in the lower plant part, formed from the base and short stolons, resulting in a bunch of stems. Their cell walls consist of more components among them, lignin - and consequently $\mathrm{N}$ levels are lower, raising the lignin/ $\mathrm{N}$ ratio, especially in the absence of $\mathrm{N}$ fertilization.

Dubeux Júnior et al. (2006a) also observed that $\mathrm{N}$ fertilization of Pensacola Bahia grass (Paspalum notatum Fluegge) pasture reduced the lignin/N ratio, which influenced the decomposition and mineralization rate of nutrients in the residue. Dubeux Júnior et al. (2006b) reported that grazing intensity influenced forage mass and fodder in this grass. However, this system indicated that this grass can store $\mathrm{N}$ and $\mathrm{P}$ through immobilization, particularly at the beginning and end of grazing, mineralizing the nutrients later for the developing crop by straw decomposition, consolidating the system by reducing nutrient loss, especially in environments with higher soil fertility, such as integrated crop-livestock under no-till systems.

Nevertheless, the lignin/ $\mathrm{N}$ ratios for straw from no-till systems in this study were lower than the ratio 7.8 found by Pariz et al. (2009a) for marandu grass, evaluated 75 days after emergence (DAE) in spring/ summer, at the same location as in this study. Given that the lignin/ $\mathrm{N}$ ratio of straw was evaluated 15 days after the last cut - in which stems predominated and few leaves were available to absorb the desiccant herbicide - the earlier phenological stage of the grasses favored the reduction of this ratio. This confirms that the lignin/N ratio may also be influenced by the leaf/ stem ratio, grass age and time of year.

In general, $\mathrm{N}$ fertilization of pasture during winter/ spring increased the straw quantity left on the soil after the last cut (Figure 3).

With regard to straw decomposition, a logarithmic regression was found for intercrops mombaça grass with maize and marandu grass at $\mathrm{N}$ fertilization, at all applied rates, intercrop tanzania grass with maize at $200 \mathrm{~kg} \mathrm{ha}^{-1}$ year ${ }^{-1}$ of $\mathrm{N}$, and intercrop marandu grass with maize without fertilization and at $400 \mathrm{~kg} \mathrm{ha}^{-1}$ year $^{-1}$ of $\mathrm{N}$, with rapid decomposition in the first 15 days after straw chopping (DAM), whereas linear and exponential regressions were observed in the other intercrops (Figure 3). In general, straw was reduced to less than $1,000 \mathrm{~kg} \mathrm{ha}^{-1} 180 \mathrm{DAM}$, due to the low lignin/N ratio of grasses (Figure 3). According to Amado (2000), crop residue decomposition is an essentially biological process involving macro, meso and microorganisms, while biotic and abiotic factors determine the decomposition speed of the process; aside from $\mathrm{K}$, most nutrients contained in these residues are released at the same rate as straw dry matter decreases.

Nutrient cycling is influenced by crop rotation and by the presence of crop residues on the soil surface. Maintaining them reduces the decomposition rate, favoring a gradual nutrient release. This synchrony between nutrient release and requirement of the developing crop is essential to reduce nutrient leaching
(Amado, 2000). Since one of the objectives of straw production, aside from the physical soil protection, was to provide nutrients for the growing maize and in view of the large amounts of straw from the previous crops in the area, it was decided to apply mechanical management with the machine of straw fragmentation to chop the straw mechanically after herbicide dessication, which may also have accelerated residue decomposition, particularly in the first 30 DAM.

Consequently, as with straw quantity (Figure 3), percentage of remaining straw in relation to the plant matter amount at cutting in intercrops mombaça grass with maize and marandu grass at $\mathrm{N}$ fertilization showed logarithmic regressions, with rapid initial decomposition. Regardless of the $\mathrm{N}$ rate in winter/ spring, approximately 40 and $50 \%$ of the straw of mombaça grass with maize and marandu grass at $\mathrm{N}$ fertilization, respectively, left on the soil surface remained there for 30 DAM (Figure 4).

Regardless of the $\mathrm{N}$ rate applied in winter/spring, 180 DAM the \% straw left of the initial amount was approximately $25,20,10,10,20$, and $15 \%$ for tanzania grass with maize, tanzania grass at $\mathrm{N}$ fertilization, mombaça grass with maize, mombaça grass at $\mathrm{N}$ fertilization, marandu grass with maize, and marandu grass at $\mathrm{N}$ fertilization, respectively (Figure 4). Decomposition of ruziziensis grass was faster in the absence of $\mathrm{N}$ fertilization, due to the more decumbent growth of this grass, which has a greater number of stems and stolon due to lower straw deposition on the soil - reaching 11.18 and $7.33 \%$ of the initial straw amount 180 DAM for ruziziensis grass with maize and ruziziensis grass at $\mathrm{N}$ fertilization, respectively. In the treatments with $\mathrm{N}$ fertilization, straw 180 DAM was greater than 30 and $20 \%$ for ruziziensis grass with maize and ruziziensis grass at $\mathrm{N}$ fertilization, respectively. However, given that maize (sown successively) generally has cycles of 120 130 days, it can be affirmed that the results were satisfactory, as more straw was left on the soil surface after the grain harvest.

Experiments with no-till systems in the tropics have indicated that this system can only develop its full potential if significant amounts of crop residue are available and researchers and producers recommend ever-increasing quantities of straw. Ruedell (1998) suggested annual amounts of $6,000 \mathrm{~kg} \mathrm{ha}^{-1}$ dry matter, while Bayer et al. (2000) recommended an addition of 10,000-12,000 kg ha-1 dry matter. In Cerrado areas, where winters are dry and warm, applications can surpass the aforementioned amounts, due to rapid residue decomposition. Thus, such high residue levels are only possible in production systems that include sidedressing, crop rotation, and more recently, integrated crop-livestock systems.

The results of this study demonstrate the potential use of the evaluated grasses as forage during winter/ spring (off-season) and as straw for no-till systems in Cerrado environments. Although the amount of grass 


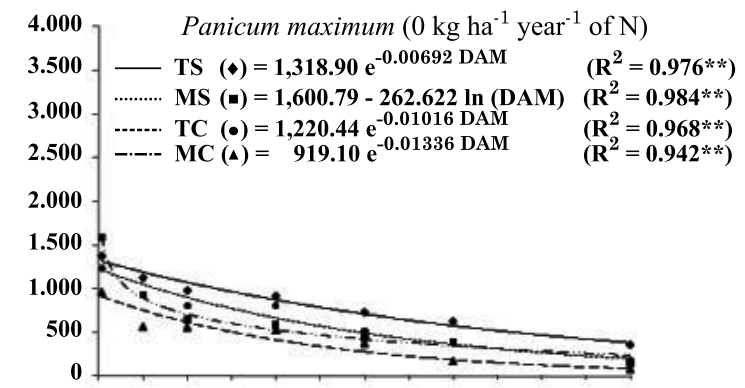

Panicum maximum $\left(200 \mathrm{~kg} \mathrm{ha}^{-1} \mathrm{year}^{-1}\right.$ of $\left.\mathrm{N}\right)$
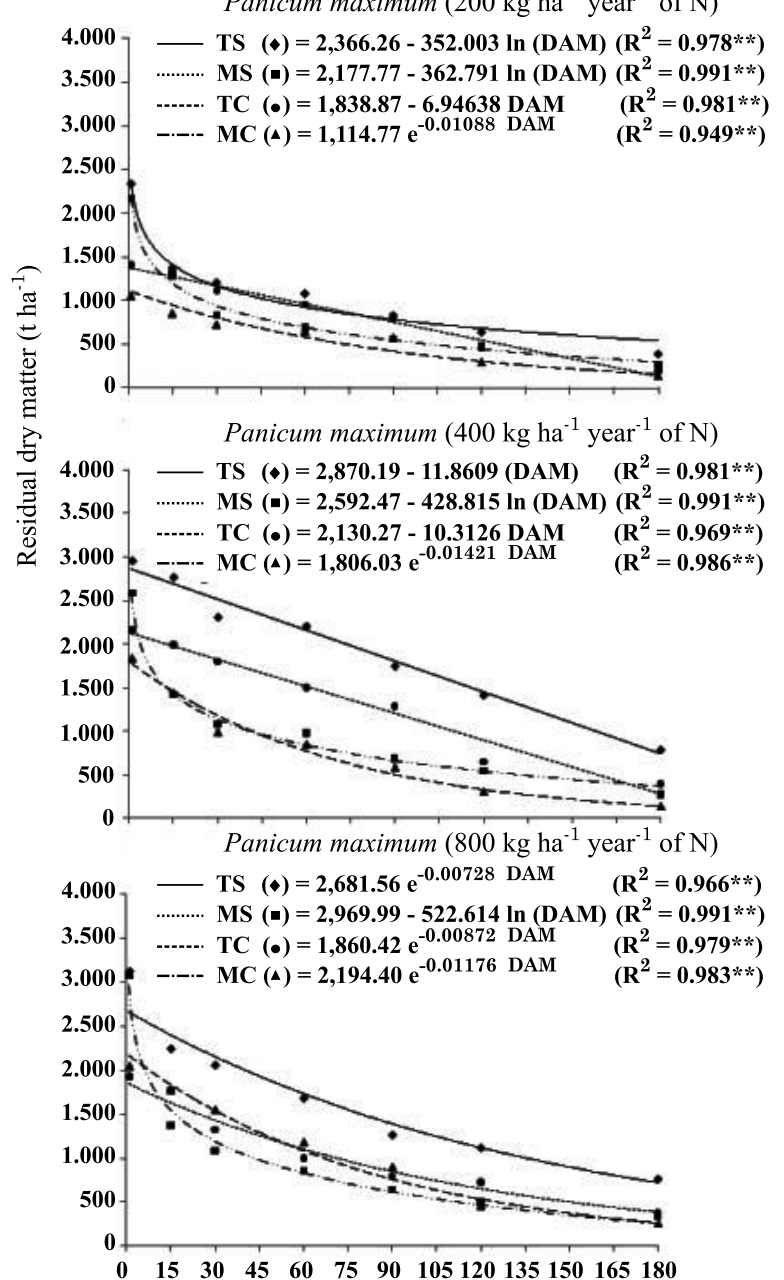

Brachiaria brizantha $\left(0 \mathrm{~kg} \mathrm{ha}^{-1} \mathrm{year}^{-1}\right.$ of $\left.\mathrm{N}\right)$

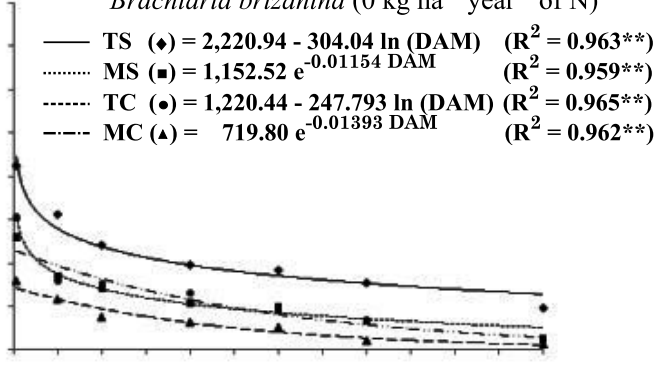

Brachiaria brizantha $\left(200 \mathrm{~kg} \mathrm{ha}^{-1} \mathrm{year}^{-1}\right.$ of $\left.\mathrm{N}\right)$

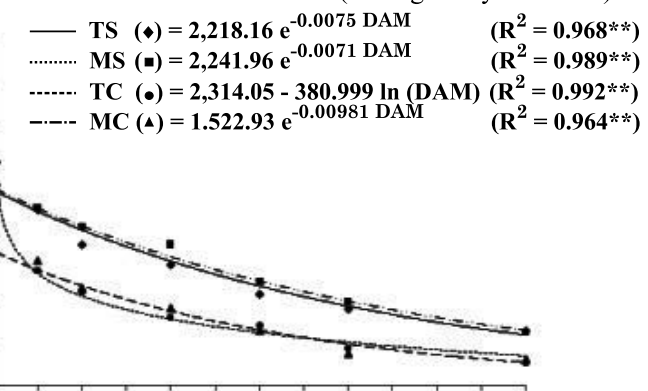

Brachiaria brizantha $\left(400 \mathrm{~kg} \mathrm{ha}^{-1} \mathrm{year}^{-1}\right.$ of $\left.\mathrm{N}\right)$
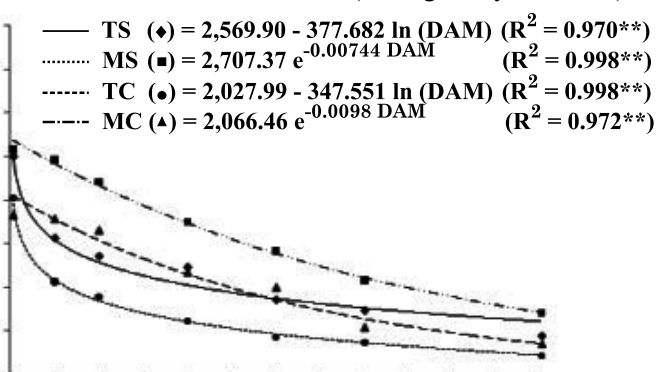

Brachiaria brizantha $\left(800 \mathrm{~kg} \mathrm{ha}^{-1}\right.$ year $^{-1}$ of $\left.\mathrm{N}\right)$

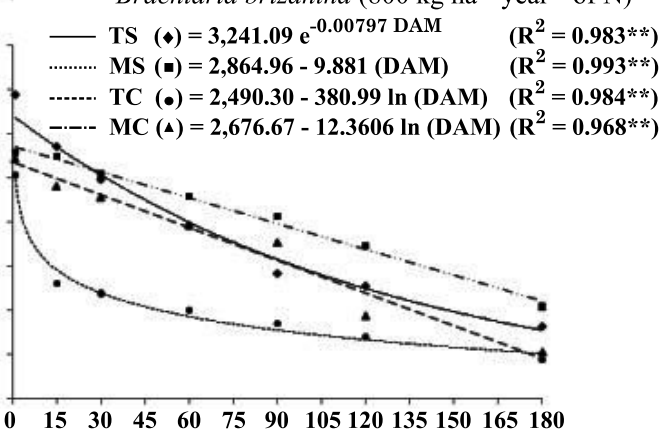

Day after management (DAM)

Figure 3. Straw decomposition (residual dry matter) of Panicum maximum cv. Tanzânia, $P$. maximum cv. Mombaça, Brachiaria brizantha cv. Marandu and B. ruziziensis grown intercropped with maize, Nfertilized (applied at four cuts) and chopped after the last cut in winter/spring. TS, MS, BS and RS: Panicum maximum cv. Tanzânia, $P$, maximum cv. Mombaça, Brachiaria brizantha cv. Marandu and $B$. ruziziensis sown together with maize, respectively; TC, MC, BC and RC: Panicum maximum cv. Tanzânia, Panicum maximum cv. Mombaça, Brachiaria brizantha cv. Marandu and Brachiaria ruziziensis sown at the time of $\mathrm{N}$ side dressing of maize, respectively. ${ }^{* *}:(\mathrm{p}<0.01)$.

straw left on the soil surface was below $3,000 \mathrm{~kg} \mathrm{ha}^{-1}$, when added to the straw from maize intercropped with these same grasses, the total would probably reach $12,000 \mathrm{~kg} \mathrm{ha}^{-1}$ of dry matter, since results by Borghi et al. (2004) at the same study location demonstrated that maize in no-till systems can potentially produce $9,000 \mathrm{~kg} \mathrm{ha}^{-1}$ of straw dry matter.
Therefore, when implementing no-till systems, crops should be sidedressed to increase the straw production capacity, straw should persist once left on the soil surface (high lignin/ $\mathrm{N}$ ratio), and mineral recycling should be efficient, as a gradual source of nutrients. In 5 to 10 year long no-till systems, as in this study, organic matter and straw begin to 


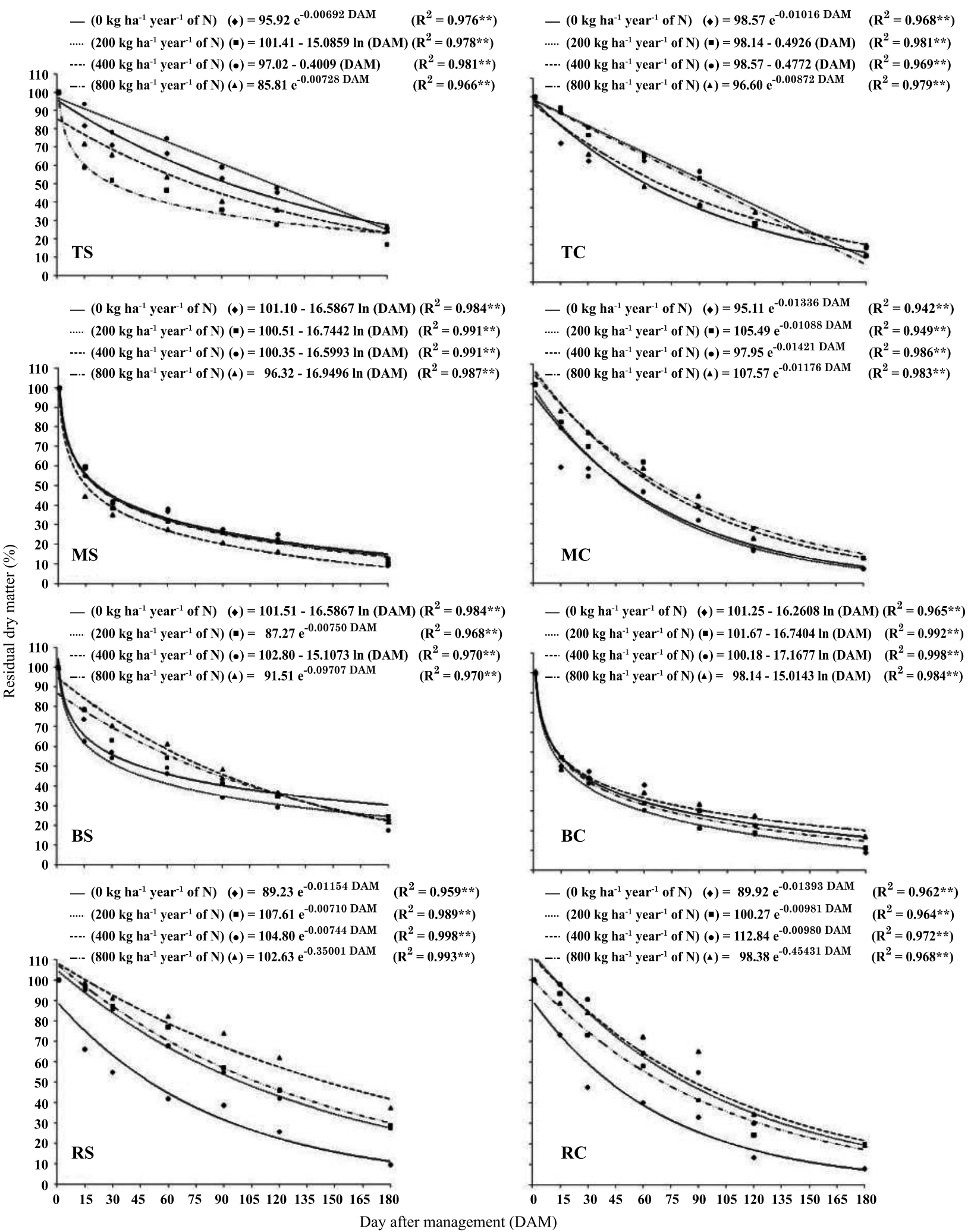

Figure 4. Straw decomposition percentage (residual dry matter) of Panicum maximum cv. Tanzânia, $P$. maximum cv. Mombaça, Brachiaria brizantha cv. Marandu and B ruziziensis grown intercropped with maize, $\mathrm{N}$-fertilized (applied at four cuts) and chopped after the last cut in winter/spring. TS, MS, BS and RS: Panicum maximum cv. Tanzânia, P. maximum cv. Mombaça, Brachiaria brizantha cv. Marandu and B. ruziziensis sown together with maize, respectively; TC, MC, BC and RC: Panicum maximum cv. Tanzânia, P. maximum cv. Mombaça, Brachiaria brizantha cv. Marandu and B. ruziziensis sown at the time of $\mathrm{N}$ side dressing of maize, respectively. **: $(\mathrm{p}<0.01)$. 
accumulate on the soil surface, and the values of immobilized $\mathrm{N}$ approached $\mathrm{N}$ mineralization. This indicates that species with rapid nutrient availability in straw should be used, to reduce dependency on and minimize costs of fertilization in the subsequent grain crop.

A higher number of tillers and consequently better pasture establishment resulted in a greater amount of straw in the simultaneous sowing of maize treatments and raising $\mathrm{N}, \mathrm{P}$ and $\mathrm{K}$ quantities deposited by straw to the soil surface (Table 1). Due to the faster regrowth and larger stems, marandu grass sown with maize resulted in the highest $\mathrm{N}, \mathrm{P}$ and K input via straw to the soil surface. Independent of the treatment, the regressions of N, P and $\mathrm{K}$ input via straw to the soil surface were positive and linear. These results demonstrate that besides the nutrients extraction through the cuts in the winter/spring periods, the residual $\mathrm{N}$ fertilization promotes grass growth and deposition of nutrients by grasses straw, aimed at continuity of the no-till system.

\section{CONCLUSIONS}

1. Nitrogen fertilization of tanzânia, mombaça, marandu and ruziziensis grass in winter/spring after intercropping with irrigated maize in an integrated crop-livestock system under no-tillage proved to be a technically feasible alternative to increase the input of straw and N, P and K left on the soil surface, required for the sustainability of this system.

2. A low lignin/ $\mathrm{N}$ ratio of straw combined with high temperatures accelerate straw decomposition, reducing the initial quantity to about 30, 90 days after chopping.

\section{LITERATURE CITED}

AMADO, T.J.C. Manejo da palha, dinâmica da matéria orgânica e ciclagem de nutrientes em plantio direto. In: ENCONTRO NACIONAL DE PLANTIO DIRETO NA PALHA, 7., Foz do Iguaçu, 2000. Anais... Ponta Grossa, FEBRAPDP, 2000. p.105-111.

Table 1. Nitrogen, phosphorus and potassium input via straw to the soil surface of Panicum maximum cv. Tanzânia, Panicum maximum cv. Mombaça, Brachiaria brizantha cv. Marandu and Brachiaria ruziziensis grown intercropped with maize, N-fertilized (divided in four cuts) and chopped after the last cut in winter/spring. Selvíria-MS. 2008/2009

Treatments (intercropping grasses)

$\frac{\text { Nitrogen rate }\left(\mathrm{kg} \mathrm{ha}^{-1} \text { year }^{-1}\right)}{800}$

Regression equation

$\mathbf{R}^{2}$

$\begin{array}{llll}0 & 200 & 400 & 800\end{array}$

Nitrogen input via straw to the soil surface $\left(\mathrm{kg} \mathrm{ha}^{-1}\right)$

Tanzania grass with maize
Tanzania grass at $\mathrm{N}$ fertilization
Mombaça grass with maize
Mombaça grass at $\mathrm{N}$ fertilization
Marandu grass with maize
Marandu grass at $\mathrm{N}$ fertilization
Ruziziensis grass with maize
Ruziziensis grass at $\mathrm{N}$ fertilization

$\begin{array}{rlrr}16.1 & 32.4 & 46.6 & 53.8 \\ 13.5 & 20.3 & 33.2 & 33.6 \\ 14.5 & 28.8 & 39.3 & 54.2 \\ 9.3 & 15.0 & 29.4 & 38.5 \\ 24.9 & 35.3 & 39.3 & 69.5 \\ 14.4 & 32.7 & 31.0 & 44.6 \\ 11.9 & 27.8 & 39.2 & 48.9 \\ 7.7 & 21.2 & 29.1 & 51.6 \\ & \text { CV }=21.27(\%) & \end{array}$

$$
\begin{array}{ll}
\hat{y}=21.18+0.0458 \mathrm{~N} & 0.8835^{\text {** }} \\
\hat{y}=16.13+0.0258 \mathrm{~N} & 0.7852^{* *} \\
\hat{y}=17.22+0.0485 \mathrm{~N} & 0.9741^{\text {** }} \\
\hat{\mathrm{y}}=9.74+0.0380 \mathrm{~N} & 0.9464^{* *} \\
\hat{\mathrm{y}}=23.01+0.0550 \mathrm{~N} & 0.9598^{* *} \\
\hat{\mathrm{y}}=18.98+0.0334 \mathrm{~N} & 0.8413^{* *} \\
\hat{\mathrm{y}}=16.31+0.0447 \mathrm{~N} & 0.9194^{* *} \\
\hat{\mathrm{y}}=8.60+0.0537 \mathrm{~N} & 0.9949^{* *}
\end{array}
$$

\begin{tabular}{|c|c|c|c|c|c|c|}
\hline & & & & & & \\
\hline Tanzania grass with maize & 3.1 & 6.0 & 6.9 & 7.7 & $\hat{y}=4.09+0.0052 \mathrm{~N}$ & $0.7856^{\text {** }}$ \\
\hline Tanzania grass at $\mathrm{N}$ fertilization & 2.8 & 3.2 & 5.1 & 4.6 & $\hat{y}=3.07+0.0025 \mathrm{~N}$ & $0.6027^{* *}$ \\
\hline Mombaça grass with maize & 4.7 & 5.6 & 6.9 & 8.1 & $\hat{\mathrm{y}}=4.79+0.0043 \mathrm{~N}$ & $0.9700^{* *}$ \\
\hline Mombaça grass at $\mathrm{N}$ fertilization & 2.2 & 2.7 & 4.6 & 5.1 & $\hat{\mathrm{y}}=2.32+0.0039 \mathrm{~N}$ & $0.8750^{* *}$ \\
\hline Marandu grass with maize & 4.8 & 6.5 & 5.8 & 10.0 & $\hat{y}=4.66+0.0060 \mathrm{~N}$ & $0.8511^{\text {** }}$ \\
\hline Marandu grass at $\mathrm{N}$ fertilization & 2.9 & 5.2 & 4.7 & 6.2 & $\hat{\mathrm{y}}=3.53+0.0035 \mathrm{~N}$ & $0.7595^{* *}$ \\
\hline Ruziziensis grass with maize & 3.7 & 5.4 & 6.9 & 7.3 & $\hat{y}=4.30+0.0043 \mathrm{~N}$ & $0.8301^{* *}$ \\
\hline \multirow{2}{*}{\multicolumn{7}{|c|}{ nuziziensis grass al iv iertillzation }} \\
\hline & & & & & & \\
\hline \multicolumn{7}{|c|}{ Potassium input via straw to the soil surface $\left(\mathrm{kg} \mathrm{ha}^{-1}\right)$} \\
\hline Tanzania grass with maize & 25.8 & 49.1 & 62.4 & 68.2 & $\hat{y}=33.93+0.0498 \mathrm{~N}$ & $0.8149^{* *}$ \\
\hline Tanzania grass at $\mathrm{N}$ fertilization & 22.4 & 29.9 & 43.7 & 42.8 & $\hat{y}=25.56+0.0260 N$ & $0.7396^{* *}$ \\
\hline Mombaça grass with maize & 29.4 & 50.4 & 59.1 & 71.6 & $\hat{y}=35.31+0.0494 N$ & $0.9059^{* *}$ \\
\hline Mombaça grass at $\mathrm{N}$ fertilization & 21.0 & 27.0 & 47.3 & 50.6 & $\hat{y}=22.77+0.0392 \mathrm{~N}$ & $0.8338^{* *}$ \\
\hline Marandu grass with maize & 39.8 & 53.6 & 52.8 & 88.6 & $\hat{y}=38.14+0.0588 \mathrm{~N}$ & $0.9186^{* *}$ \\
\hline Marandu grass at $\mathrm{N}$ fertilization & 24.3 & 47.8 & 40.6 & 55.7 & $\hat{y}=30.68+0.0326 \mathrm{~N}$ & $0.6930^{* *}$ \\
\hline Ruziziensis grass with maize & 24.3 & 48.7 & 59.2 & 65.0 & $\hat{y}=32.85+0.0470 \mathrm{~N}$ & $0.7936^{* *}$ \\
\hline Ruziziensis grass at $\mathrm{N}$ fertilization & 17.4 & 38.5 & 46.8 & 67.5 & $\hat{\mathrm{y}}=21.72+0.0595 \mathrm{~N}$ & $0.9636^{* *}$ \\
\hline \multicolumn{7}{|c|}{$\mathrm{CV}=19.36(\%)$} \\
\hline
\end{tabular}

Phosphorus input via straw to the soil surface $\left(\mathrm{kg} \mathrm{ha}^{-1}\right)$

\footnotetext{
${ }^{* *}$ : significant at $1 \%$.
} 
BALBINOT JÚNIOR, A.A.; MORAES, A.; VEIGA, M.; PELISSARI, A. \& DIECKOW, J. Integração lavourapecuária: Intensificação de uso de área agrícolas. Ci. Rural, 39:1925-1933, 2009

BAYER, C.; MIELNICZUK, J.; AMADO, T.J.C.; MARTINNETO, L. \& FERNANDES, S.V. Organic matter storage in a sandy clay loam Acrisol affected by tillage an cropping systems in southern Brazil. Soil Tillage Res., 54:101-109, 2000 .

BORGHI, E.; MELLO, L.M.M. \& CRUSCIOL, C.A.C. Adubação por área e por planta, densidade populacional e desenvolvimento do milho em função do sistema de manejo do solo. Acta Sci. Agron., 26:337-345, 2004.

CRUSCIOL, C.A.C. Qualidade química do solo. In: DECHEN, S.C.F., org. WORKSHOP SOBRE O SISTEMA PLANTIO DIRETO NO ESTADO DE SÃO PAULO, 2005, Campinas. Anais... Piracicaba, 2007. p.103-114.

DUBEUX JÚNIOR, J.C.B.; SOLLENBERGER, L.E.; INTERRANTE, S.M.; VENDRAMINI, J.M.B. \& STEWART JÚNIOR, R.L. Litter decomposition and mineralization in Bahiagrass pastures managed at different intensities. Crop Sci., 46:1305-1310, 2006a.

DUBEUX JÚNIOR, J.C.B.; SOLLENBERGER, L.E.; VENDRAMINI, J.M.B.; STEWART JÚNIOR, R.L. \& INTERRANTE, S.M. Litter mass, deposition rate, and chemical composition in Bahiagrass pastures managed at different intensities. Crop Sci., 46:1299-1304, $2006 \mathrm{~b}$.

EMPRESA BRASILEIRA DE PESQUISA AGROPECUÁRIA EMBRAPA. Centro Nacional de Pesquisa do Solo. Sistema brasileiro de classificação de solos. 2.ed. Rio de Janeiro, 2006. 306p.

FERREIRA, D.F. SISVAR: Sistema de análise de variância. Lavras, UFLA/DEX, 1999.

GARAY, A.H.; SOLLENBERGER, L.E.; McDONALD, D.C.; RUEGSEGGER, G.J.; KALMBACHER, R.S. \& MISLEVY, P. Nitrogen fertilization and stocking rate affect stargrass pasture and cattle performance. Crop Sci., 44:1348-1354, 2004.

KLIEMANN, H.J.; BRAZ, A.J.B.P. \& SILVEIRA, P.M. Taxas de decomposição de resíduos de espécies de cobertura em Latossolo Vermelho distroférrico. Pesq. Agropec. Trop., 36:21-28, 2006.

KLUTHCOUSKI, J.; COBUCCI, T.; AIDAR, H.; YOKOYAMA, L.P.; OLIVEIRA, I.P.; COSTA, J.L.S.; SILVA, J.G.; VILELA, L.; BACELLOS, A.O. \& MAGNABOSCO, C.U. Sistema Santa Fé - Tecnologia Embrapa: Integração lavoura-pecuária pelo consórcio de culturas anuais com forrageiras, em áreas de lavoura, nos sistemas direto e convencional. Santo Antonio de Goiás, Embrapa Arroz e Feijão, 2000. 28p. (Circular Técnica, 38)
KLUTHCOUSKI, J.; STONE, L.F. \& AIDAR, H. Integração lavoura-pecuária. Santo Antônio de Goiás, Embrapa Arroz e Feijão, 2003. 570p.

KLUTHCOUSKI, J. \& STONE, L.F. Palhada de braquiária no sistema plantio direto. In: KLUTHCOUSKI, J.; STONE, L.F. \& AIDAR, H., ed. Integração lavoura-pecuária. Santo Antônio de Goiás, Embrapa Arroz e Feijão, 2003. p.497533.

MALAVOLTA, E.; VITTI, G.C. \& OLIVEIRA, S.A. Avaliação do estado nutricional das plantas: Princípios e aplicações. 2.ed. Piracicaba, Associação Brasileira para Pesquisa da Potassa e do Fosfato, 1997. 319p.

PARIZ, C.M.; ANDREOTTI, M.; AZENHA, M.V.; ARAÚJO, F.C.M.; BERGAMASCHINE, A.F. \& BUZETTI, S. Tempo de decomposição de massa seca de espécies forrageiras em função de épocas de semeadura no cerrado. 2009a Disponível em: <http://www.diadecampo.com.br/ zpublisher/materias $/$ Materia.asp? secao $=$ Pacotes Tecnológicos\&id=20478>. Acesso em: 27 abr. de 2010.

PARIZ, C.M.; ANDREOTTI, M.; TARSITANO, M.A.A.; BERGAMASCHINE, A.F.; BUZETTI, S. \& CHIODEROLLI, C.A. Desempenhos técnicos e econômicos da consorciação de milho com forrageiras dos gêneros Panicum e Brachiaria em sistema de integração lavoura-pecuária. Pesq. Agropec. Trop., 39:360-370, $2009 \mathrm{~b}$.

PARIZ, C.M.; ANDREOTTI, M.; BERGAMASCHINE, A.F.; BUZETTI, S.; COSTA, N.R.; CAVALLINI, M.C.; ULIAN, N.A. \& LUIGGI, F.G. Yield, chemical composition and chlorophyll relative content of Tanzania and Mombaça grasses irrigated and fertilized with nitrogen after corn intercropping. R. Bras. Zootec., 40:728-738, 2011.

RAIJ, B.van; ANDRADE, J.C.; CANTARELLA, H. \& QUAGGIO, J.A. Análise química para avaliação da fertilidade de solos tropicais. Campinas, Instituto Agronômico de Campinas, 2001. 285p.

RUEDELL, J. A soja numa agricultura sustentável. In: SILVA, M.T.B., ed. A soja na rotação de culturas no plantio direto. Cruz Alta, Fundacep/Fecotrigo, 1998. p.1-34.

SILVA, D.J. \& QUEIROZ, A.C. Análise de alimentos: Métodos químicos e biológicos. 3.ed. Viçosa, MG, Universidade Federal de Viçosa, 2002. 235p. 
